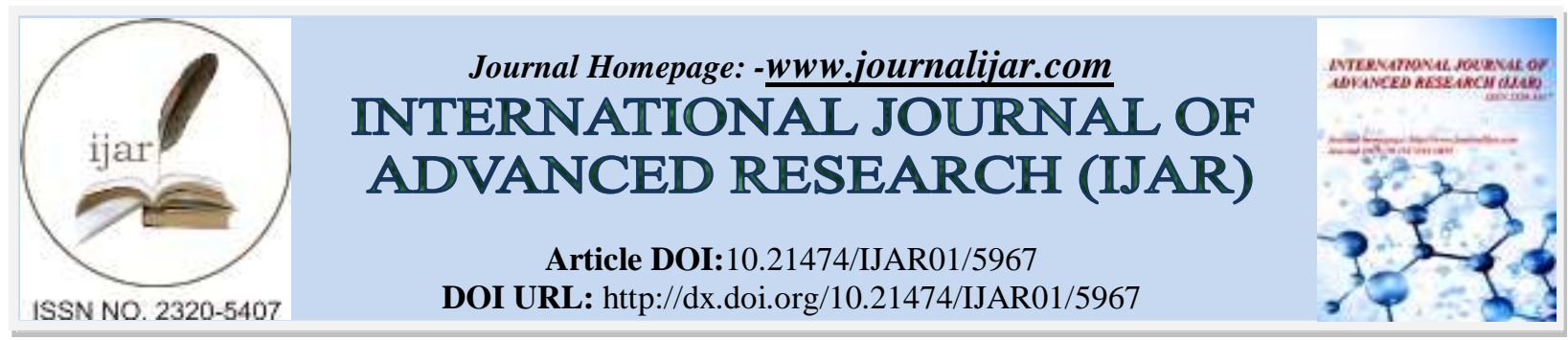

RESEARCH ARTICLE

\title{
LITERATURE REVIEW ON WORKING CAPITAL MANAGEMENT.
}

\section{Ms Divya P. Solanki.}

Research scholar of r.k. University at rajkot, Kadiyavad street no.1,b/h chanadatara building -upleta-360490. Assistant professor: Mirambika College of Management Rajkot.

\section{Manuscript Info}

Manuscript History

Received: 04 October 2017

Final Accepted: 06 November 2017

Published: December 2017

Key words:-

Working Capital Management, components of working capital management, cash conversion cycle, inventory turnover in days, Bills payable in days, Bill receivables in days.

\section{Abstract}

In depth analysis tells that most in case research work is observed and focused mainly on two aspects, working capital on profitability of firm and working capital management.The chief issues with previous literature are lack of survey-based approach and lack of methodical theory advance study, which gives direction and idea for future research. The proposed future research direction is given in this paper may help to develop a better understanding of determinants and practices of working capital management.

Copy Right, IJAR, 2017,. All rights reserved.

\section{Introduction:-}

Working capital management plays an important role in financial management of the industry. Numbers of researcher has been done the research on different components of working capital and subjects on. Here, I have included the relevant articles as well research work on the same topic and subject. And this is a part of my research work on the same title the working capital management of selected textile companies of India. The main aim of this paper is to identify the gaps in current body of my research work which gives the direction towards forward attention to be given.

\section{NCEAR (1966):-}

The National council of applied Economic Research (NCEAR) in 1966 first time formal study was conducted on working capital management in India. The council published a structure of working capital" which was limited analysis of the creation of working capital with special attention to the fertilizers, and cement and sugar industries the main objective of this study was emphasized on come out with findings that working capital management practices were extremely unplanned and hence need to develop proper accounting policies like inventory management, debtors management as above. And the study suggested developing suitable working capital policies required in the success of business.

\section{Bhatt V. V. (1972):-}

He has given concentration on system to appraise working capital management and its finance specially for the large scale companies. This tools also helpful to other sectors like agriculture as well retail trade etc. As bank provide short term finance to operation of business at the same time need to pay attention on repayment of loan and required finance necessity. If these two area is to be maintain properly no need to appraise the working capital management concern. 


\section{Smith Keith V. (1973):-}

Research has been given focused on the short term finance need to be given more attention for the success of the individual firm. For that finance manager has to give more attention on current assets and current liability. Many firms do investment of current assets in a basket while current liability in many different request. This paper consist eight distinct approaches to working capital management out of it first three gives common guidelines next three regarding constrain set and cost balancing and last two about probability models and portfolio theory.

\section{Chakraborthy S. K. (1974) :-}

In this research author try to make difference among cash working capital v/s balance sheet working capital. And research is based on two dimensions.

Fist is operating cycle concept and second calculation of operating cycle period in all the four cases. Main aim of this research is to exhibit operating cycle concept based on published annual report of the firm.

\section{Misra (1975):-}

Here, in this analysis try to identify the problems of working capital in six public enterprises for the period of 1960. Importance and findings are here under: selected samples of companies were not able to utilize working capital efficiently. As well excess inventory level which shows inappropriate management of inventory. In order delay exchange was made to foreign exchange and issue of import license. Furthermore account receivable ratio is very law because liberal credit policy and inappropriate collection policy. In most of the selected firms were having huge cash amount on account and improper management and control on cash.

NatarajanSundar (1980) has been given views on working capital is having immense important at both, the national as well business level. To keep control on working capital at the national level by controlling credit controls. In practice efficient working capital includes to determine the best suitable level of working cpaital, financing it and control over it. If we talked about corporate level investment is important in both case short term investment and fixed assets. And that can be possible many company not surviving as well not incurring profit because of not efficiently manage the working capital. Thus, cost management with improved operational efficiency, and that aspect working capital is very important to be manage in proper way.

\section{Rajeshwar (1985):-}

He has done the study on few selected public enterprises in India. He tried to check the working capital policies adopted by the sample units. He made attempt to examine the working capita components how efficiently managed. At the last no one company clearly defined working capital polices and hence most of them could not achieve efficiency in working capital management. In this study it is found that majority of investment was made in finished goods inventory that was indicate that working capital was not managed in planned way. Thus, study recommended for careful management of working capital in finance management.

\section{Rao K.V. and RaoChinta (1991):-}

This study observed that strong and weak point of conventional techniques of working capital analysis. Outcomes of this study shows that some of the conventional techniques which could realized the working capital behavior well.

And some of them fail to do so. And thus authors suggest proper working capital management with conventional method i.e. ratio analysis. Study suggests further inclusive factors which are decisive yardstick in working capital efficiency.

Fazzari Steven M. and Petersen Bruce C. (1993) :-

Research has been put light on financial restrain on investment by giving focus the ignoring role of working capital in both as use and source of funds. As per the views of author liquidity can be maintain by maintaining working capital on smooth manner means to be investment in a manner which does not create cash flow constrain. Through the research found that working capital investment should be "excessively sensitive" with summing up that controlling on smoothing working capital create a long term impact of finance constraints and reported in many other studies also.

Siddharth and Das (1994):-

Siddharth and Das has been done study on "Working Capital Turnover in Pharmaceutical companies" tried to determine efficient use of working capital in selected pharmaceutical firms in India. 10 years data has been 
concluded that overall turnover ratio was 90.3 time. the finely analysis of the data shows that the selected companies has done well in terms of employment of working capital. Further more study discovered the working capital turnover ratio cried off staidly over the stage from $1981-1990$.

\title{
Vijayakumar and Venkatachalam (1995):-
}

This study was made on observed analysis in working capital and profitability.

Study was carried with 13 firms belonging sugar industry for the 10 years period from 1982-1983 to 1991-92. The correlation and regression statistical method has been used to analyze the impact of working capital ratios on profitability. In this study total four ratios has been taken in to consideration; Liquidity ratio, inventory turnover ratio, receivable turnover ratio and cash turnover ratio. The discovery of the study said that liquid ratio and cash turnover ratio have harmful impact on profitability on the other hand inventory turnover ratio and receivables Have positive impact on profitability.

\section{Rafuse (1996):-}

The article stressed on working capital enhancement by halting payment of creditors. That was clear many UK companied delayed payment for the long period. Very surprisingly the story reveled in 1994 by the Forum for Private Business, that was a small business association, and reverse side 50 days before payment of debtors were been paid beyond the due date. This article stressed to maintain healthy and close relationship among supplier and customer. The discovery of the study warranted the firms to reduce inventory level as fast as possible in order to increase the profit of the firms. Another fact of study was that control over working capital responsibility goes on the head of finance manager.

\section{Swamy (1997):-}

Swamy was done research with 19 key agricultural area in the contour of Dakshina Kannada district in Karnataka. The research exposed that maintenance of liquidity and profitability is a major problem in the targeted are. To be safe in side of working capital management were found to be suffered and low profitability due to the interest burden. The effects of this firms raised the fund for working capital requirement by borrowing fund from depositors. This study has been given stressed on proper management of working capital so the future of business would be bright.

\section{HossainSaiyedZabid and Akon Md. HabiburRahman (1997) :-}

The main objective of this study is to maintain working capital in proper way. i.e. time of fund requirement, amount of fund and from where to raise fund to be maintain so can possible to acquire trade off among liquidity and profitability. The analysis showed that BTMC had followed aggressive working capital policy by taking the risk of liquidity. The study analyzed that company continuously raising trend in negative net working capital during the period of the study. That was suggest to BTMC not to raise only fund from long term source instead by understating the requirement of fund need to take short term source also.

\begin{abstract}
Ahmed Habib (1998):-
This study is evaluated that the interest rate of fund reducing money power on output. For the study rational expectation model is used to find out relation between production decisions and debt finance. As working capital having immense important factors and its cost, the rate of interest, affects the supply of goods, this study revealed that this model helps to identify the alarming situation when interest rate is used. This model also revealed that effects of monetary policy on the price level and supply side.
\end{abstract}

\section{GargPawan Kumar (1999):-}

This study was done in selected public sectors firms of Hariyana study relate with working capital and liquidity analysis. The analysis of the study says that forecasting of working capital necessity constrained on different factors. After realizing the facts like needs of working capital in public sectors. According to that, need to analyze production schedule, labor cost, sales trend etc. furthermore, suggestion is to manage other components of working capital.

Bansal S. P. (1999):-

Review of this study on working capital management refers to the management of current assets and current liabilities to be maintain the various components to increasing the profitability of the firm. The author persists on 
application of various methods and techniques for the management of working capital and its three main gears cash, receivables and inventors.

RaoGovinda D. and Rao P. M. (1999) :-

As per the study management of working capital is constant process. So that proper observation on various components is needed. At the end relationship between different components are needed. This provides proper direction.

Hyon - Han Shin an LUC Soemen (1998):-

The study is on the efficiency of the working capital management and business profitability. There are 58 companies are taken for the research and period for the study is 1975 to 1994 , study found that there is a strong negative relationship if firm having long Net Trade Cycle and its profitability. In other side short Net Trading cycle created the risk. It has also found measuring liquidity differently, need to be maintain appropriate current ratio having positive relation with profitability.

Singh O. N. (1999):-

The research discussed the needs of credit to the farmers or agriculture segment and another need is having proper system of working capital finance in agriculture segment in line and commerce finance, with some changes. Research advised a system which is quite similar useful and fulfill the need of both farmers as well as the bankers. Main aim of the study is to make farmers strong in terms of capital.

RaoGovinda D. and Rao P. M. (1999):-

Study believes that management of working capital is a constant process need of finance proper observation or monitoring and revising the relationship of all variables and give conclusion. This is a proper indication to the manager.

Dutta (2000):-

Author Dutta has done study on "Working Capital Management of Horticulture Industry in Humachal Pradesh" that was a case study of Himachal Pradesh Horticulture Produce Marketing and Processing Corporation for the stage 1991 to 1998. The study was thrown the light on financing pattern of working capital management. The study exposed that the working capital of HRMC was going worse gradually during the study period. Though, huge losses of the firm holding the huge amount of inventory and that was a main cause of failed trade off among liquidity and profitability. The conclusion of study like that there was no significant correlation between gross working capital and sales.

Jain P. K. and YadavSurendra S. (2001):-

That was a study of corporate Working capital management related practices in India, Singapore and Thailand. This study tried to understand the relationship of working capital management and current assets and current liabilities. In other hand, authors have revealed the analysis liquidities ratios like current assets and current liabilities. Every sample of study have been pertained these ratios for the management of working capital. In a sum up of the paper the data of samples of three countries confirm that there were wide inter-industry variations in liquidity ratios. At the end, authors suggest the serious consideration attention to be given by respective nation as well industry groups of three companies and should develop corrective measures to take care of areas concern.

\section{Parvathy (2004):-}

Observation of study has shown that in increasing in mode, but net profit has in decreasing in trend because operating cost is high. The others found out and thrown light on the importance of cost of production. Other side found that the return on network and the return to total assets were on the decreasing trend. Researcher has found that the return on investment is stable and the company invested on profitable way. Company's payout ratio was very conservative and that shows growth of the company. With sum up of the research is that for the long term financial stability and formed the debt equity ratio. Opposite side of the research interest coverage ratio and the proprietary ratio were not satisfactory.

Filbeck Greg and Krueger Thomas M. (2005):-

As per the article, need to study internal working capital management and working capital performance. That article was published in CFO magazines. As per the findings of this article macro economic factors, interest rates, 
competition, etc. having impact on working capital management. Further finding is that management of working capital goes on stock prices also.

\section{MeszekWieslaw and PolewskiMarcin (2006):-}

By observation of selected construction companies at area of working capital management and working capital policy formation and strategies implication. The Study was based to develop the controlling methodology for working capital. here, study that was going on construction company having the specific factors are to be consider like functional factors and market requirements which make working capital area wide and more focused.

\section{ChowdhuryAnup and Amin Md. Muntasir (2007):-}

That was the study carried on pharmaceutical companies listed in Dhanka Stock Exchange. Observation of the study based on the financial management, according to this major problem found in area of working capital management. It is true that working capital effects go on business performance and growth. The main objective of the study is to evaluate working capital practicability and implication of working capital policy and strategies in the targeted industry. To obtain the goal, evaluation was made regarding principles, procedures and techniques of stock management, creditors' management, and debtors' management.

\section{ArindamGhosh (2007):-}

That was the study carried on Cement Industry of India specific area of study was "Working Capital Management and its practices and impact on profitability. Main aim of the study is to evaluate efficiency of working capital management of selected cement companies in India during the period 1992 to 2001 . For the study targeted 20 large cement companies avail in India having very large portion in cement industry of India.

\section{Samiloglu F. and Demirgunes K. (2008):-}

The objective of the study is to examine effect of working capital management on firm's prosperity. The study carried with manufacturing companies listed in Istanbul Stock Exchange (ISE) the tenure for the study is 1989 to 2007. For the study multi regression statistical method is used. Observed come outs of study revealed that some factors having negative impact and some having positive impact on profitability of firms. Positive factors like growth of sale on other hand debtors' payment period, stock conversion period as well as debt interest negatively affects firms' profitability.

\section{ViraniVarsha (2008):-}

It was a comparative study in CADILA COMPANY

This study has been done with certain objectives first is to examine financial performance and second one is to examine profitability trend and at the last to find out assets operational model and evaluate liquidity position of the company. To achieve these goals used two classy analytical tools i.e. ratio analysis and correlation analysis. The study shows relationship between different ratios. That is also observed that correlation and coefficient is near about so there is a high degree of negative and positive correlation between various ratios.

\section{RamachandranAzhagaiah and JanakiramanMuralidharan (2009):-}

In this study author examine the relationship among working capital management proficiency and earnings before interest and tax. The study was made on Paper industry in India during 1997 to 2005. For the measurement of working capital management three indexes are taken into consideration performance index, utilization index and efficiency index, and EBIT of the selected companies for the study period are taken. As a conclusion of the study says paper companies of india performed well during period. Some having very good index and some of them need to improve the working capital management give proper attention on that particular area also.

\section{Kushwah, Mathur\&Ball(2009):-}

The study undergone to evaluate the working capital management and direction in selected five major cement companies i.e. ACC, Grasim, Ambuja, Prism and Ultra- Tech.. For the research purpose secondary data are used like authors collected the financial statement of selected cements companies for the years from 2007 to 2009 . There is liquidity ratios and activities ratios are used to analyse the condition of working capital of the companies. The study revealed the truth of study is that, most companies not maintain their working capital in a systematic way while overall ACC shows appropriate management of working capital. 


\section{Rao and Rao\&Ramachandran (2010):-}

Main aim of his study is to evaluate the trends and parameters of effectiveness of working capital and its utilization in terms of volume of the firms of cotton textiles industry in India. For that three parameters are taken i.e. different indices first one performance Index, utilization index and efficiency Index. For the study industry is divided in three category means small, medium and large. The output of the study is like that linear growth rate model is used to find out the significance with working capital and PI,UI and EI are significant in respect of small size companies while in medium size only UI is significant. On an average we can say that working capital efficiency was not so satisfied despite having PI in growth mode. The reason behind is that continuous factors are declining.

\section{Rahman Mohammad M. (2011):-}

Research is based on correlation among working capital and profitability. To analyze the effectiveness of working capital management of the selected textile companies.conclusion of the study found that overall good management in working capital management of selected textile companies and thus most of the companies are profitable way going on.

Dr Arbab Ahmed and Dr Matarneh Bashar (2011):-

Research carried with registration technique which is very powerful statistical tool to forecast the working capital. the area of working capital management, that is possible to make the projection after starting the average relationship in the past. For the purpose different components are used and to be finalized result. And it is presented in diagrammatic way as well mathematical way.

Dr KaddumiThair A. and Dr Ramadan Imad Z. (2012):-

The evaluation was made in 49 jordanian companies they are listed in Amman Stock Exchange, The carried with topic like effect of working capital management on the profitability in a targeted companies for the period 2005 to 2009. This goal could be achieved with help of two different measures one is for profitability and another one is for performance of working capital management i.e. proxy and five proxies use full for respective goal. For the estimation two regression models fixed effects model and ordinary least model are used.

Kaur Harsh V. and Singh Sukhdev (2013):-

This article focuses on cash conversion efficiency and setting up the operating cycle days. The study tests the relationship between the working capital attain and profitability calculated by income to current assets and income to average total assets. Authors did study with companies listed in BSE 200 that is spread over 19 industries for the period 2000 to 2010.At the end, the study lay emphasis on that proficient management of working capital notably affects profitability.

\section{Madhavi K. (2014):-}

She has done research based on empirical study of co relation among liquidity position an profitability of the paper mills in Andhra Pradesh. That has been evaluated ineffective working capital negatively effect on profitability of the paper mills.

Gurumurthy N. and Reddy Jayachandra K. (2014):-

He has conducted serve and observed working capital management position in four pharmaceutical companies APSPDCL, APEPDCL, APNPDCL and APCPDCL and come out with fact that working capital management was not so good in position and need to do beteer.

\section{Conclusion:-}

Most of the existing studies reveal with different measurement technique to analyze the financial performance is yet to develop. With this view the present study has been analyzed. The different researchers have been done the research with different industry as well different tools techniques and with different factors which are related with working capital management and profitability of the corporate area. 


\section{Bibliography:-}

1. Gurumurthy N. and Reddy Jayachandra K. (2014) https://www.worldwidejournals.com April_2014_1397564396_76a32_3.p...Volume : 3 | Issue : 4 | April 2014 • ISSN No 2277 - 8160

2. Madhavi K. (2014) www.Impacjournals.us 2, Issue 3, Mar 2014, 63-72 Working Capital Management

3. Kaur Harsh V. and Singh Sukhdev (2013) Asian Journal of Business Management 5(2) 197-207, 2013

4. Mr. N.SureshBabu IRACST- International Journal of Research in Management \& Technology (IJRMT), ISSN: 2249-9563 Vol. 4, No.5, October 2014 Study on the Working Capital ManagementEfficiency in Indian Leather Industry- An Empirical Analysis

5. DrKaddumiThair A. and Dr Ramadan Imad Z. (2012) www.researchgate.net Profitability and Working Capital Management The Jordanian 962-795-004-334

6. Rahman Mohammad M. (2011)

7. Rao and Rao\&Ramachandran (2010) (Published in Asia Pacific Journal of Management

8. Kushwah, Mathur\& Ball(2009) https://www.researchgate.net/../publication

9. RamachandranAzhagaiah and Janakiraman Muralidharan2009) National Publishing House Volume $7 \cdot$ Number 12009. 